\title{
Rates of Sexual Maturation of Atlantic Cod in NAFO Division 5Ze and Commercial Fishery Implications
}

\author{
J. J. Hunt \\ Gulf of Maine Section, Biological Station \\ St. Andrews, New Brunswick, Canada E0G 2X0
}

\begin{abstract}
An analysis of maturity data for Georges Bank cod (Gadus morhua) in NAFO Division 5Ze, derived from Canadian 1986-94 spring research surveys, showed a significant decrease in the total length $(\sim 4 \mathrm{~cm})$ and age $(\sim 0.5$ years) of fish at fifty percent maturity, over the nine year period. Differences in mean size-at-age for males and females appeared to occur after the age at which full maturity was achieved, allowing the use of data pooled by sex for estimating maturity ogives by length and age. Maturity ogives, derived from the prefishery survey data, were adjusted for growth and used to estimate commercial landings of immature cod. Results indicated that over $40 \%$ by number and $20 \%$ by weight of the 1987 catch was of juvenile cod from the 1985 year-class. However, the average 1987-93 catch of juveniles was substantially lower at $15 \%$ by number and $6 \%$ by weight with a decrease in the latter part of the time series. Estimates based on maturity-at-length and at age gave similar results but length was considered the better estimator.
\end{abstract}

Key words: Cod, commercial fishing, Georges Bank, maturity

\section{Introduction}

The current stock management zone used by Canada for Georges Bank (Fig. 1) cod (Gadus morhua) consists of Canadian Fisheries Statistical unit areas $j$ and $m$ in NAFO Division 5Ze (a zone referred to as $5 Z \mathrm{j}, \mathrm{m}$ ). Definition of this zone is based on analysis of cod tagging data and research survey distribution studies which showed an apparent discontinuity between the eastern and western part of the 5Ze area (Hunt, MS 1989). The USA considers the management zone to consist of a large area of $5 Z \mathrm{Ze}$ and Subarea 6 (Anon, MS 1994a). The 5Zj,m zone is bisected by the international maritime boundary, adopted in 1985, into Canadian (5Zc) and USA (5Zu) zones.

A commercial fishery in the $5 \mathrm{Zj}, \mathrm{m}$ zone is carried out by both Canada and the USA, with each country restricted to their respective side of the international boundary since 1985. Annual evaluations of stock status have been completed by Canada using data from the post-1978 time period (Hunt and Buzeta, MS 1994).

Mesh size regulations for $<65 \mathrm{ft}$ vessels using bottom trawl gear have been in effect for a number of years and these vessels are currently restricted to $145 \mathrm{~mm}$ (1993), $155 \mathrm{~mm}$ (1994) diamond or 130 $\mathrm{mm}$ square mesh. Use of larger mesh size is presumed to have some conservation effect by limiting catches of small immature fish which have no market value.
The purpose of the present study was to estimate growth parameters and maturity ogives from research survey data and to evaluate annual changes. The derived ogives were used to determine the maturity composition of the stock and spawning stock biomass (SSB) and to estimate catches of juveniles in the commercial fishery.

O'Brien (MS 1990) provides a detailed synopsis of life history parameters, including maturity analyses, for the Georges Bank cod stock in the period 1970-87. O'Brien et al., (1993) report more recent estimates of maturation rates for a number of Georges Bank finfish. However, their analyses used data based on a USA defined maturity schedule and collected in April, after peak spawning has occurred (Burnett et al., MS 1989).

\section{Methods}

Canada has conducted annual stratified random research bottom trawl surveys of the Georges Bank area in February/March since 1986 and samples of cod were obtained for length frequency, age and maturity stage. The survey typically sampled the entire Georges Bank population during the peak of the observed December/April spawning period for Georges Bank cod (Burnett et al., MS 1989), and maturity stage was considered to be representative of spawning activity of individual cod during the spawning season. This implied that fish assessed to be immature during the survey would not have spawned until a subsequent years' spawning pe- 


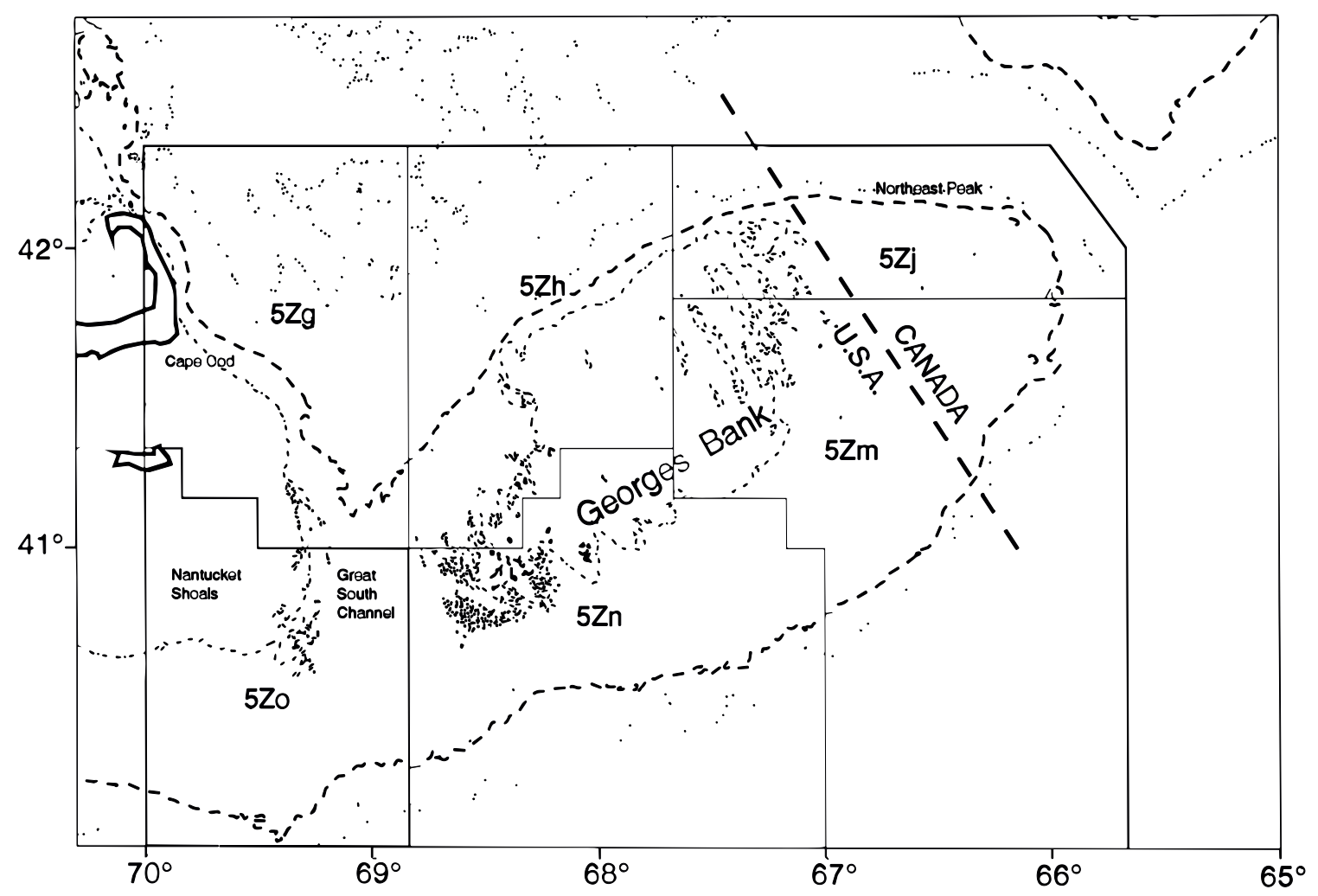

Fig. 1. Canadian fisheries statistical unit areas in NAFO Division 5Ze.

riod. Juvenile fish sampled later in the year, during the commercial fishery, may have shown some evidence of pre-spawning development but would still be considered virgin spawners.

Age and maturity samples were based on a length stratified sample design, with a maximum of three observations per $3 \mathrm{~cm}$ interval for each sampled length frequency. Maturity assignment was based on classification into eight stages of which the first was considered immature. Stages 2 through 8 were representative of the annual maturity cycle for sexually mature fish (Appendix I). Approximately 7600 observations for age and maturity stage were taken over the nine year survey time series (Table 1).

Assignment to year-class was based on the interpretation of otoliths for estimating the age of individual fish. Protocol for assigning ages is documented by Buzeta et al. (MS 1992), and they report good precision for both inter- and intra-reader age comparisons.

Sex was initially included as a parameter in the study because of the possibility of sex-specific differences in the onset of maturation. Its impact was assessed by comparing mean size-at-age for males and females, proportion mature-at-length for males and females, and the ratio of males to females in the population. To evaluate sex-specific maturation rates with age as a covariate, regression analysis was used.

Population numbers-at-length were calculated using a stratified random survey design estimator (STRAP), in which the mean catch-per-tow within strata were prorated to stratum area and then aggregated to the total survey area (Smith and Somerton, 1981). Length frequency data were not recorded by sex, and it was necessary to assume that fish subsampled for detailed observation were representative of the ratio of males to females.

Estimates of maturity at length and age by sex were determined using the 1986-94 research survey data from the $5 \mathrm{Zj}, \mathrm{m}$ area. Individual cohort estimates were obtained from consecutive surveys. For maturity analysis, only fish in the 25-65 cm length range were included since the data indicated that fish outside of this range were either all immature $(<25 \mathrm{~cm})$ or all mature $(>65 \mathrm{~cm})$. Use of cutoff points did not result in any significant difference in the estimated regression parameters or derived length $(43.10036 \mathrm{~cm}$ for the entire data set and 43.10046 for the subset) or age, and avoided the potential influence of precocious smaller fish and sterile larger fish. 
TABLE 1. Summary of cod sampling in the Canadian spring surveys in $5 Z \mathrm{j}, \mathrm{m}$.

\begin{tabular}{|c|c|c|c|c|c|c|c|c|}
\hline \multirow[b]{2}{*}{ Years } & \multirow[b]{2}{*}{ Dates } & \multicolumn{2}{|c|}{ Calendar } & \multirow[b]{2}{*}{ Immature } & \multirow[b]{2}{*}{ Mature } & \multicolumn{2}{|c|}{ Stages } & \multirow[b]{2}{*}{ Total } \\
\hline & & Day & $\mathrm{C}^{0}$ & & & $2 \& 8$ & $4,5 \& 6$ & \\
\hline 1986 & $04-13.03$ & 67.5 & 6.6 & 159 & 387 & 231 & 41 & 546 \\
\hline 1987 & $10-18.03$ & 73.2 & 4.7 & 139 & 228 & 69 & 63 & 367 \\
\hline 1988 & $01-15.03$ & 66.5 & 5.3 & 141 & 839 & 305 & 185 & 980 \\
\hline 1989 & $23.02-06.03$ & 59.8 & 5.7 & 291 & 773 & 230 & 245 & 1064 \\
\hline 1990 & $21.02-06.03$ & 58.0 & 5.5 & 172 & 1200 & 274 & 480 & 1372 \\
\hline 1991 & $13-27.02$ & 55.2 & 6.0 & 201 & 1013 & 193 & 304 & 1214 \\
\hline 1992 & $25.02-09.03$ & 64.0 & 5.2 & 132 & 790 & 266 & 258 & 922 \\
\hline 1993 & $09-18.03$ & 74.3 & 5.3 & 42 & 660 & 180 & 253 & 702 \\
\hline 1994 & $14-25.02$ & 50.1 & 5.4 & 64 & 400 & 177 & 128 & 464 \\
\hline
\end{tabular}

For each survey the proportion mature-atlength was determined by dividing the number in stages 2-8 by the total number of observations. The proportions immature and mature were prorated to the population numbers using the following algorithm:

$$
P_{s, m, j}=\left(N_{a, s, m, j} \times N_{j}\right) /\left(N_{a, s, i, j}+N_{a, s, m, j}\right)
$$

$$
\begin{aligned}
& \text { where } N_{s, m, j} \quad=\text { stratified number mature at } \\
& \text { length } \mathrm{j} \text {, } \\
& \mathrm{N}_{\mathrm{s}, \mathrm{i}, \mathrm{j}}=\text { stratified number immature at } \\
& \text { length }{ }_{j} \text {, } \\
& \mathrm{N}_{\mathrm{i}} \quad=\text { total number in length frequency } \\
& \text { at length }{ }_{j} \text {, } \\
& \mathrm{P}_{\mathrm{s}, \mathrm{m}, \mathrm{j}} \quad=\text { total number mature at length }{ }_{\mathrm{j}} \text {, } \\
& \mathrm{s} \quad=\operatorname{sex} 1 \text { or } 2 \text { (male or female), and } \\
& \text { a }=\text { age. }
\end{aligned}
$$

This model is consistent with generalized models used for estimating population parameters from two phase sampling designs and conforms to the recommendations of ICES (1994). The calculations required construction of age/length keys for each of the four male, female, mature and immature combinations, and the resultant four matrices, prorated to the population provided the necessary information to determine maturity-by-sex, -age and -length.

Ogives of maturity-at-length were derived using a logistic model ( $\mathrm{Ni}$ and Sandeman, 1984; O'Brien et al., 1993; Trippel and Harvey, 1991) of the form:

$$
\begin{aligned}
& P=1 /\left(1+e^{(a+b x)}\right) \\
& \text { where } \mathrm{P}=\text { proportion mature, } \\
& \times \quad=\text { length in } \mathrm{cm} \text { (combined or by year- } \\
& \text { class), and } \\
& \mathrm{a}, \mathrm{b}=\text { estimated model parameters. }
\end{aligned}
$$

Parameter estimates were obtained using the nonlinear regression application of the STATGRAPHICS analysis package (CSTSC, Inc). Lengths corresponding to fifty percent mature $\left(L_{50}\right)$ were derived from the regression coefficients as $[-a / b]$.

An index of SSB was derived for each survey using the estimated population numbers-at-length of mature females and a length/weight relationship derived from aggregated 1986-94 survey observations. The index of female SSB was estimated as the sum of:

$$
\mathrm{FSSB}=\sum_{1}^{\mathrm{n}} \mathrm{N}_{\mathrm{fl}} \times \mathrm{P}_{\text {mature }} \mathrm{W}_{\mathrm{l}}
$$

where $\mathrm{N}=$ survey abundance of mature females-at-length / for the observed range,

$\mathrm{w}=$ calculated mean weight-at-length $/$,

and

$$
\mathrm{P}=\text { percent mature-at-length } \mathrm{I} \text {. }
$$

Canadian landings of Georges Bank cod are sampled for length frequency and age by Port Technicians of the Marine Fish Division stationed at Yarmouth and Lockeport, Nova Scotia. The USA also collects samples of commercial landings but the present analysis was restricted to the Canadian sampling and landings in the fishery. Length frequencies from annual commercial landings were derived using the method described by Hunt and Buzeta (MS 1994). Length frequencies by gear sector were weighted to reported landings and then combined by gear sectors to provide an annual estimate of catch-at-length.

Maturity observations were generally not taken in routine landings samples since most fish were landed in gutted condition. To evaluate the proportion of immature fish in commercial landings, it was necessary to adjust length for elapsed time between the annual date of the survey and the fishery. A von 
Bertalanffy growth model, with age in days, was used for this adjustment.

The growth model, survey and fishery dates ((landings $\times$ calendar day)/total landings $)$ ) were used to adjust length with the following algorithms:

$$
\begin{aligned}
& \mathrm{A}_{\text {Irv }}=\text { model predicted age-at-length } \\
& I \text { in the survey } \\
& =\mathrm{t}_{0}+\left(\ln \left(1-\left(\mathrm{l} / \mathrm{L}_{\text {inf }}\right)\right) /-\mathrm{k}\right) \text {, for } \\
& \text { length }=31 \text { to } 130 \mathrm{~cm} \\
& \mathrm{~L}_{\mathrm{c}}=\text { model predicted length-at-age } \\
& \left(A_{\text {Irv }}\right. \text { plus (commercial - survey } \\
& \text { calendar date)), }
\end{aligned}
$$

and

$$
\mathrm{L}_{\text {adj }}=\text { commercial length }-\mathrm{L}_{\mathrm{c}} .
$$

\begin{tabular}{|c|c|c|c|}
\hline where & $P_{i m}$ & $=$ & proportion immature, \\
\hline & $P_{1}$ & $=$ & $\begin{array}{l}\text { proportion mature-at-length / in } \\
\text { the survey, and }\end{array}$ \\
\hline
\end{tabular}

This adjustment provided an annual commercial fishery length equivalent to that which would have been observed in the preceding winter survey. The proportion mature at this adjusted length was estimated using length from the survey and annual survey maturity ogives as shown below:

$$
P_{\text {im }}=\sum_{1}^{n}\left(P_{1} \times N_{\left(I+I_{\text {adj }}\right)}\right) \div \sum_{1}^{n}\left(N_{l}\right)
$$

$\mathrm{N}$ is the number of fish-at-length $\left(I+L_{\text {adj }}\right)$ in the fishery.

A similar analysis was completed using maturity-at-age applied to commercial landings-at-age from Hunt and Buzeta (MS 1994). In this approach, the annual proportion mature-at-age from each of the 1986-93 surveys was used to partition the estimated annual landings-at-age. The sum of the immature component was expressed as a proportion of the total number of fish landed

$$
\begin{aligned}
\mathrm{P}_{\mathrm{im}} & =\sum_{1}^{\mathrm{n}}\left(\mathrm{P}_{\mathrm{a}} \times \mathrm{N}_{\mathrm{a}}\right) \div \sum_{1}^{\mathrm{n}} \mathrm{N}_{\mathrm{a}} \\
\text { where } \quad \mathrm{P}_{\mathrm{im}} & =\text { proportion immature, } \\
\mathrm{P}_{\mathrm{a}} & =\begin{array}{l}
\text { proportion mature-at-age } \mathrm{a} \text { in } \\
\text { the survey, and }
\end{array}
\end{aligned}
$$

$\mathrm{N}$ is the number-at-age a in the fishery.

\section{Results}

Criteria used to assign maturity stage from macroscopic examination are shown in Appendix I after References.

The calculated mean lengths-at-age for males and females for ages 1-14 in 1987-93 are given in
Table 2. There appeared to be a trend in length-atage between males and females, with the latter generally being larger-at-age. The difference in mean length-at-age for each survey year is shown in Fig. 2. Estimated von Bertalanffy growth parameters for each sex and year are also given in Table 2 and the resultant predicted values for the 1987-93 mean are shown in Fig. 3. A t-test between mean length for males and females indicated a significant (at 95\% level) effect in all years. An analysis of variance with sex and year as variates (Table 3 ) indicates that the effect of sex on length-at-age did not become significant until ages $4+$, the age at which most fish have reached maturity. The apparent lack of either sex or year effects for ages 7 and 8 was probably due to low sample size and associated high variance for the mean.

The proportion of females in the population by length group is shown in Fig. 4 and the summed proportions are given in Table 4. Males appeared to dominate at lengths $<100 \mathrm{~cm}$ but females were more abundant at lengths $>100 \mathrm{~cm}$. Females accounted for about 44-54 percent of the total population for 1986-94 with a mean of 49 percent.

Derived maturity ogives by sex and year are summarized in Table 5. A t-test indicates no significant (at 95\% level) difference in the proportion mature-at-length between males and females. A substantial offset for 1987 females appeared to be an artifact of sampling and the high numbers of the 1985 year-class taken at age two as well as an anomalous high proportion of immature females in the 46-50 cm length range. The net effect of these factors was a decrease of the slope of the 1987 ogive, and a shift of the ogive to the right.

Regression analysis of proportion mature-atlength for ages two and three, and sex, was completed with the difference in proportion for males and females at the same age and length within years considered as the dependent variable, and length considered as the independent variable. Results indicated no significant difference from zero in either the intercept or slope estimates for either the individual or the 1986-94 mean values at age two or age three.

Analyses which included sex as a variate indicated no significant differences in the proportion mature-at-length between males and females over the lengths at which first maturity occurs, although the difference in size at ages 4 plus was significant. Since the primary objective of the study was assessment of the onset maturity and that the impact of differing growth rates occurred after sexual maturity, subsequent analysis used data pooled by sex. 


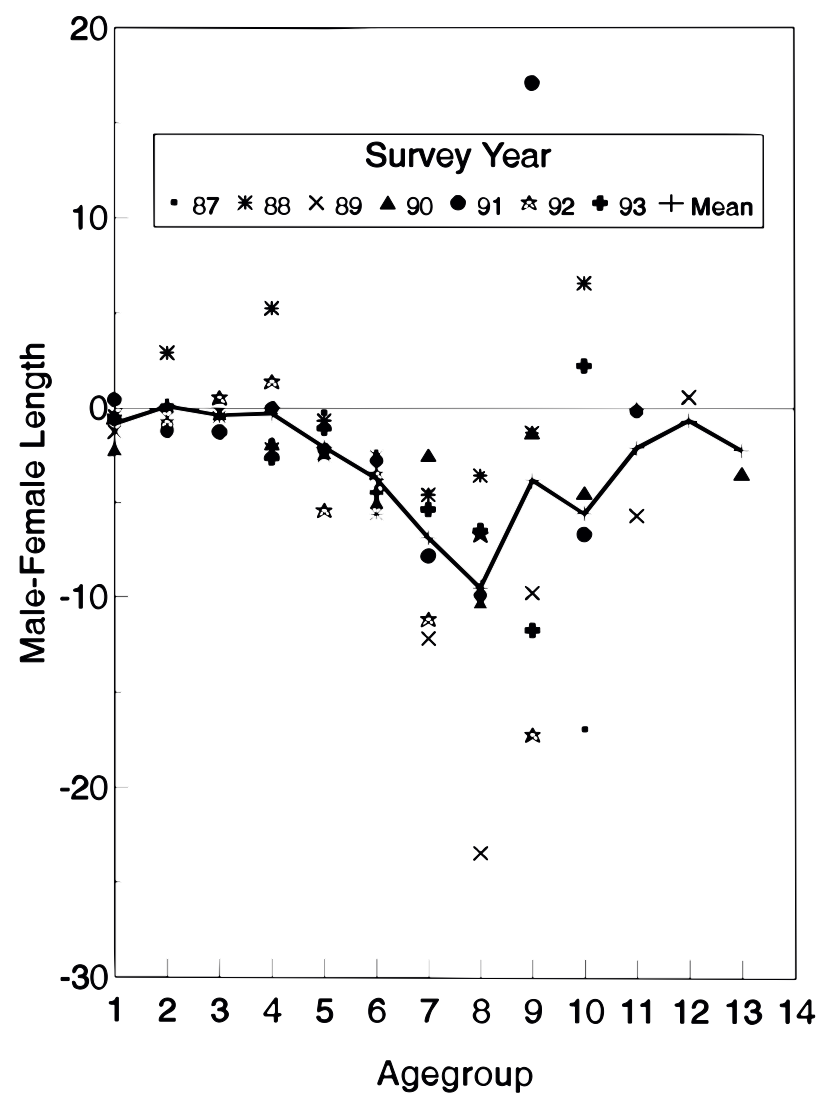

Fig. 2. Male-female difference in size-at-age for Georges Bank cod.

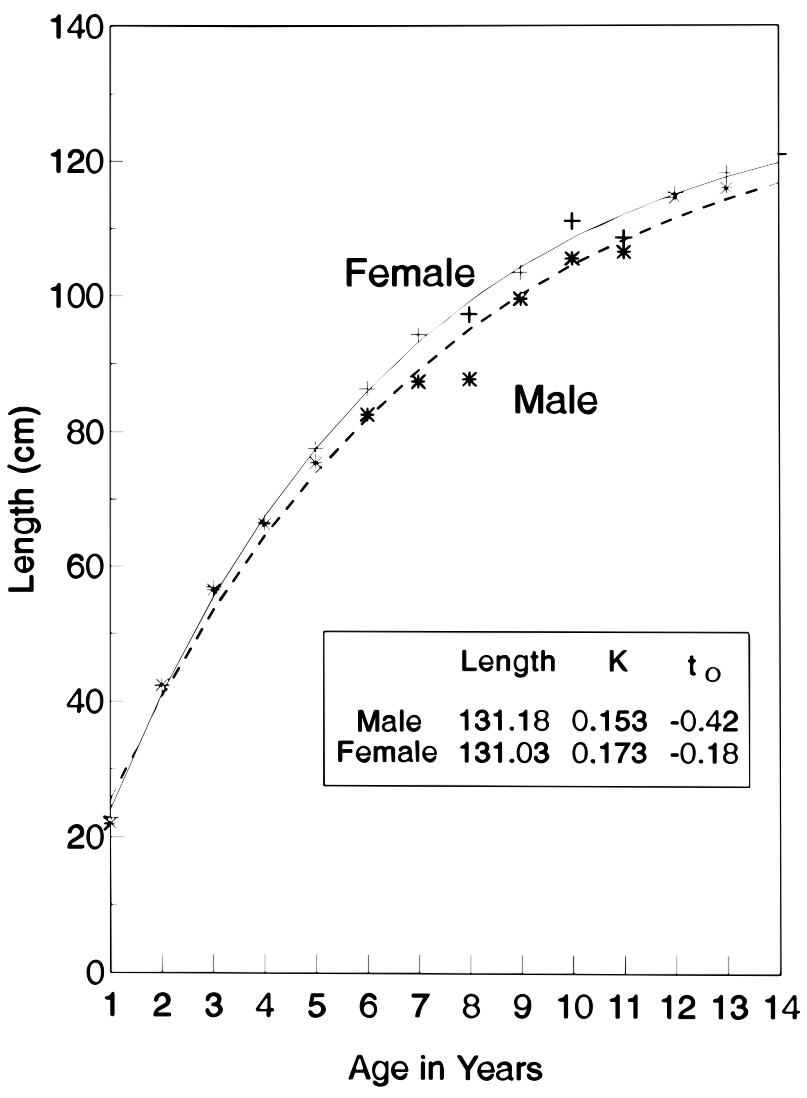

Fig. 3. Calculated annual growth curves for the 198793 mean length-at-age for males and females.

TABLE 2. Mean length-at-age of male and female cod from Canadian spring surveys in 5Zj, $\mathrm{m}$.

\begin{tabular}{|c|c|c|c|c|c|c|c|c|c|c|c|c|c|c|c|c|}
\hline \multirow[b]{2}{*}{ Age } & \multicolumn{2}{|c|}{1987} & \multicolumn{2}{|c|}{1988} & \multicolumn{2}{|c|}{1989} & \multicolumn{2}{|c|}{1990} & \multicolumn{2}{|c|}{1991} & \multicolumn{2}{|c|}{1992} & \multicolumn{2}{|c|}{1993} & \multicolumn{2}{|c|}{ Mean } \\
\hline & $M$ & F & M & $\mathrm{F}$ & M & $\mathrm{F}$ & M & $\mathrm{F}$ & M & F & M & $\mathrm{F}$ & M & F & M & F \\
\hline 1 & 21.1 & 22.3 & 22.0 & 22.5 & 24.3 & 25.6 & 22.1 & 24.4 & 21.2 & 20.7 & 23.3 & 23.7 & 20.2 & 20.7 & 22.0 & 22.8 \\
\hline 2 & 42.3 & 42.2 & 41.0 & 38.1 & 42.6 & 43.1 & 39.3 & 39.2 & 44.2 & 45.4 & 43.7 & 44.4 & 44.0 & 43.8 & 42.4 & 42.3 \\
\hline 3 & 56.1 & 55.7 & 56.2 & 56.5 & 55.9 & 56.4 & 56.1 & 56.4 & 57.7 & 59.0 & 57.5 & 56.9 & 55.8 & 57.1 & 56.5 & 56.8 \\
\hline 4 & 64.6 & 66.3 & 68.0 & 62.8 & 64.3 & 66.5 & 65.7 & 67.6 & 68.2 & 68.2 & 68.6 & 67.2 & 64.3 & 66.9 & 66.2 & 66.5 \\
\hline 5 & 80.3 & 80.5 & 77.0 & 77.7 & 74.4 & 76.9 & 74.7 & 77.1 & 73.8 & 76.0 & 72.2 & 77.7 & 75.4 & 76.5 & 75.4 & 77.5 \\
\hline 6 & 88.8 & 91.1 & 84.3 & 89.9 & 83.5 & 86.1 & 82.4 & 87.4 & 77.4 & 80.2 & 81.2 & 84.7 & 80.3 & 84.8 & 82.6 & 86.3 \\
\hline 7 & 90.9 & 95.4 & 93.7 & 98.3 & 84.7 & 96.8 & 90.6 & 93.1 & 84.2 & 92.0 & 84.9 & 96.1 & 82.8 & 88.2 & 87.4 & 94.3 \\
\hline 8 & 87.8 & 94.0 & 94.7 & 98.3 & 80.1 & 103.5 & 87.9 & 98.2 & 91.1 & 101.0 & 88.7 & 95.4 & 84.0 & 90.5 & 87.7 & 97.3 \\
\hline 9 & & 102.1 & 106.2 & 107.5 & 101.4 & 111.2 & 105.9 & 107.2 & 102.1 & 85.0 & 89.5 & 106.7 & 92.2 & 104.0 & 99.6 & 103.4 \\
\hline 10 & 104.1 & 121.0 & 118.0 & 111.4 & 97.0 & & 106.7 & 111.2 & 110.7 & 117.4 & & & 96.6 & 94.3 & 105.5 & 111.1 \\
\hline 11 & & & 106.0 & & 100.0 & 105.7 & 112.0 & 112.0 & 108.0 & 108.1 & & & & & 106.5 & 108.6 \\
\hline 12 & & 100.0 & 109.0 & & 121.0 & 120.4 & 113.7 & & & 113.8 & & 121.0 & & 121.0 & 114.6 & 115.2 \\
\hline 13 & & 118.0 & 118.0 & & 109.0 & & 115.0 & 118.5 & 118.0 & & 118.0 & & 118.0 & & 116.0 & 118.2 \\
\hline 14 & & & & & & & & & & 121.0 & & & & & & 121.0 \\
\hline
\end{tabular}

Von Bertalanffy Growth Coefficients

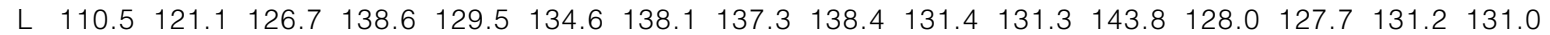

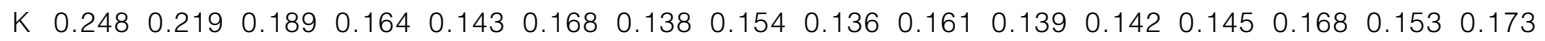
$\begin{array}{lllllllllllllllll}\mathrm{t} & 0.13 & 0.09 & -0.04 & -0.04 & -0.69 & -0.24 & -0.55 & -0.37 & -0.56 & -0.36 & -0.76 & -0.42 & -0.60 & -0.29 & -0.42 & -0.18\end{array}$ 
TABLE 3. Results of ANOVA size-at-age with sex and year as variates for cod in $5 \mathrm{Zj}, \mathrm{m}$.

\begin{tabular}{|c|c|c|c|c|c|c|c|c|c|c|c|c|c|c|}
\hline \multirow[b]{2}{*}{ Age } & \multicolumn{2}{|c|}{1987} & \multicolumn{2}{|c|}{1988} & \multicolumn{2}{|c|}{1989} & \multicolumn{2}{|c|}{1990} & \multicolumn{2}{|c|}{1991} & \multicolumn{2}{|c|}{1992} & \multicolumn{2}{|c|}{1993} \\
\hline & Sex & $\mathrm{Yr}$ & Sex & $\mathrm{Yr}$ & Sex & $\mathrm{Yr}$ & Sex & $\mathrm{Yr}$ & Sex & $Y r$ & Sex & $\mathrm{Yr}$ & Sex & $\mathrm{Yr}$ \\
\hline 1 & - & - & - & - & - & + & - & - & - & - & - & - & - & - \\
\hline 2 & - & - & - & * & - & - & - & * & - & * & - & * & - & * \\
\hline 3 & - & * & - & - & - & - & - & - & - & * & - & * & - & - \\
\hline 4 & - & - & - & - & - & - & - & - & - & - & - & - & - & - \\
\hline 5 & + & * & + & + & + & - & + & - & + & - & + & - & + & - \\
\hline 6 & * & * & * & * & * & - & * & + & * & * & * & * & * & * \\
\hline 7 & * & - & * & - & * & - & * & - & * & - & * & - & * & - \\
\hline 8 & * & - & * & - & * & - & * & - & * & - & * & - & * & - \\
\hline
\end{tabular}

* significant at $99 \%,+$ significant at $95 \%,-$ not significant

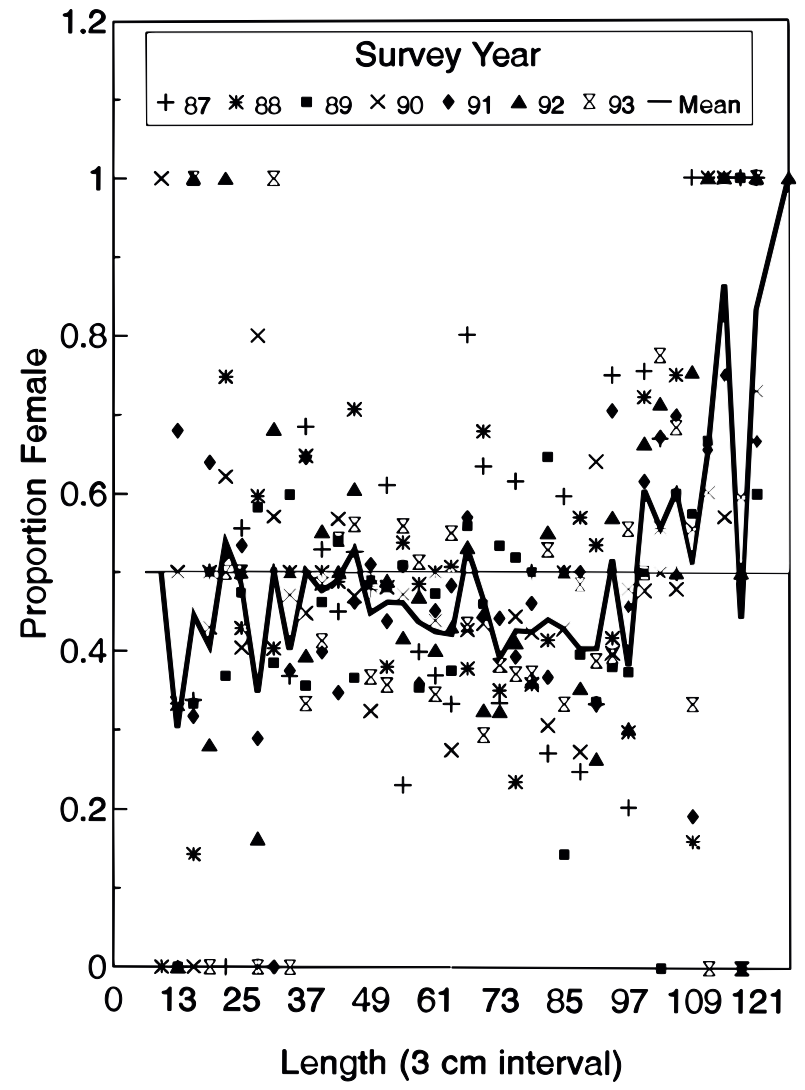

Fig. 4. Proportion of females in the population from the 1987-93 research surveys.

The proportion mature-at-length derived from survey data is shown in Fig. 5 for each of the nine surveys. In general, a small proportion of fish less than $40 \mathrm{~cm}$ were mature, about $50 \%$ were mature at $43 \mathrm{~cm}$ and almost all fish greater than $55 \mathrm{~cm}$ were mature. The transition between immature and mature fish occurred over the 30-60 cm length range with a steep slope in the range of $40-50 \mathrm{~cm}$.
Considerable annual variability in the proportion mature-at-length was evident from Fig. 5, and the annual difference at length from the mean showed some evidence of a temporal trend. The trend was even more evident when expressed as a cumulative difference (Fig. 6).

In general, fish matured at smaller lengths in the more recent part of the time series, or conversely the length at $50 \%$ maturity $\left(L_{50}\right)$ had decreased. Regression coefficients from the logistic model and the derived $L_{50}$ values are given in Table 6 , and the resultant curves are shown in Fig. 7. The $L_{50}$ decreased from a high of about $46 \mathrm{~cm}$ in 1987 to a low of about $41 \mathrm{~cm}$ in 1992 with a slight increase in 1993 and 1994. Linear regression analysis indicated a significant slope and intercept $\left(r^{2}=0.750\right)$ between year and $L_{50}$ as shown below and in Fig. 8:

$$
\begin{aligned}
& L_{50}=94.0167+\left(-.565 \times \text { Year }_{i,}\right) \\
& \text { where i }=86,94
\end{aligned}
$$

Regression coefficients from the logistic model for maturity-at-age and the derived age at 50\% maturity $\left(A_{50}\right)$ values are given in Table 7 , and the resultant curves are shown in Fig. 9. Estimates of $A_{50}$ showed a general decrease between 1986 and 1993 with a slight increase in 1994.

Comparison of stage assignment with histological characteristics for females (Sinclair, 1993; C. Annand, Marine Fish Division, Department of Fisheries and Oceans, Dartmouth, Nova Scotia, pers. com.) suggested some mis-assessment, particularly between immature and stages two and eight. The latter two stages are at the extremes of the spawning cycle. To assess the impact of excluding these stages, a separate analysis was completed using only stages $3-7$ as an indication of mature fish. The effect of excluding stages 2 and 8 for fish $<60 \mathrm{~cm}$ on the mean proportion mature-at-length is shown in Fig. 10. The two curves had a similar shape but the $L_{50}$ for the subset shifted to the right by about $5 \mathrm{~cm}$. 
TABLE 4. Proportion of males and females in the cod population in $5 Z \mathrm{j}, \mathrm{m}$ by mature group.

\begin{tabular}{lllllll}
\hline \hline & \multicolumn{2}{c}{ Males } & & \multicolumn{2}{c}{ Females } & \\
\cline { 2 - 3 } \cline { 5 - 6 } Year & 0.157 & 0.299 & 0.456 & 0.252 & 0.292 & 0.544 \\
1986 & 0.169 & 0.365 & 0.534 & 0.197 & 0.269 & 0.466 \\
1987 & 0.081 & 0.431 & 0.512 & 0.084 & 0.404 & 0.488 \\
1988 & 0.198 & 0.341 & 0.539 & 0.160 & 0.300 & 0.460 \\
1989 & 0.085 & 0.476 & 0.561 & 0.083 & 0.356 & 0.439 \\
1990 & 0.099 & 0.430 & 0.529 & 0.096 & 0.376 & 0.472 \\
1991 & 0.077 & 0.455 & 0.532 & 0.057 & 0.411 & 0.468 \\
1992 & 0.031 & 0.513 & 0.544 & 0.024 & 0.432 & 0.456 \\
1993 & 0.059 & 0.424 & 0.483 & 0.064 & 0.453 & 0.517 \\
1994 & 0.110 & 0.405 & 0.514 & 0.121 & 0.365 & 0.486 \\
Mean & & & & & &
\end{tabular}

TABLE 5. Parameter estimates for male and female using maturity ogives for cod in 5Zj,m.

\begin{tabular}{|c|c|c|c|c|c|c|}
\hline \multirow[b]{2}{*}{ Year } & \multicolumn{3}{|c|}{ Males } & \multicolumn{3}{|c|}{ Females } \\
\hline & a & $b$ & $L_{50}$ & a & $b$ & $L_{50}$ \\
\hline 1986 & -23.291 & 0.534 & 43.6 & -10.257 & 0.226 & 45.4 \\
\hline 1987 & -16.176 & 0.365 & 44.3 & -8.378 & 0.166 & 50.5 \\
\hline 1988 & -11.686 & 0.259 & 45.1 & -10.095 & 0.240 & 42.1 \\
\hline 1989 & -17.679 & 0.393 & 45.0 & -16.686 & 0.378 & 44.1 \\
\hline 1990 & -16.909 & 0.387 & 43.7 & -13.020 & 0.303 & 43.0 \\
\hline 1991 & -8.906 & 0.208 & 42.8 & -8.684 & 0.208 & 41.8 \\
\hline 1992 & -10.577 & 0.260 & 40.7 & -12.960 & 0.327 & 39.6 \\
\hline 1993 & -8.902 & 0.219 & 40.6 & -13.945 & 0.337 & 41.4 \\
\hline 1994 & -15.388 & 0.374 & 41.1 & -18.056 & 0.435 & 41.5 \\
\hline Mean & -10.614 & 0.248 & 42.8 & -10.956 & 0.251 & 43.6 \\
\hline
\end{tabular}

The number of observations in stages 2 and 8 was relatively large in some years (Table 1), which may be an indication that spawning season was more protracted when the elapsed time between active and resting stages was considered.

Only fish aged two and older showed variability in proportions mature-at-length, and all age one fish were assessed to be immature. As was the case for length alone, the earlier year-classes tend to have a smaller proportion of fish mature-at-age relative to the more recent year-classes. The calculated maturity ogives by year-class are shown in Fig. 11, and derived parameter estimates are given in Table 8 . Linear regression analysis of $L_{50}$ on year indicated a significant intercept and slope $\left(r^{2}=0.508\right)$ although the error associated with the estimates was high:

$$
\begin{aligned}
& L_{50}=95.50+\left(-0.596 \times \text { Year-class }_{i}\right), \\
& \text { where } i=84,91
\end{aligned}
$$

The proportion mature-at-ages two and three for the 1984-91 year-classes is shown in Fig. 12. The mean at age two was about 45 percent and about 90 percent at age three. There was a tendency for a higher proportion of age two fish to be mature in recent years and both the 1990 and 1991 yearclasses were about $70 \%$ mature at age two.

Comparison of annual and cohort maturity ogives for this study with those reported by O'Brien et al. (MS 1993) indicate substantial differences in the estimates of both $L_{50}$ and the shape of the derived maturity ogive. The two ogives, using the mean values from Table 5 and those reported by O'Brien et al. (MS 1993), are shown in Fig. 13. Their results indicate a more protracted progression of the onset of maturity as well as a substantial proportion of mature fish less than $30 \mathrm{~cm}$ and a lower $L_{50}$. However, the assignment to maturity stage was based on different descriptive criterion for the two studies (cf. O’Brien et al., MS 1993, pg 3).

A length/weight relationship was derived from the pooled survey observations of individual fish length and fish weight using a multiplicative regres- 


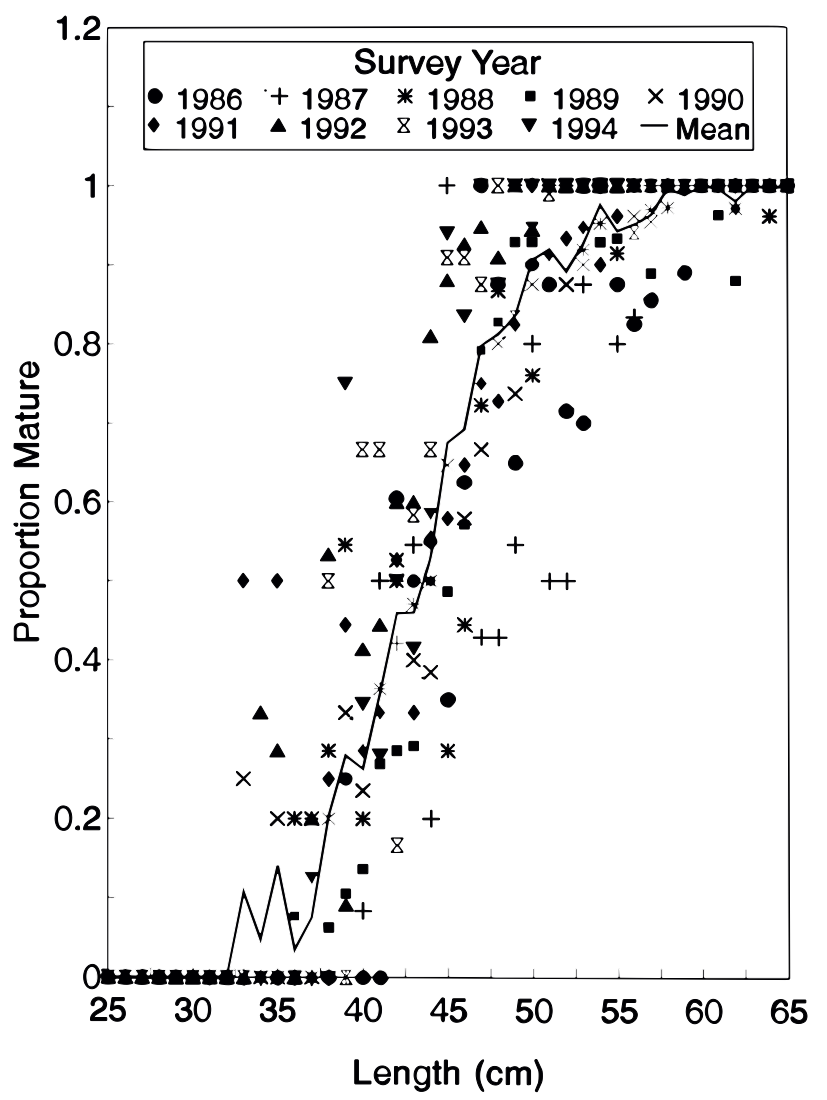

Fig. 5. Proportion of mature-at-length for Georges Bank cod during 1986-94 spring research surveys.

TABLE 6. Parameter estimates for maturity ogives by survey year for cod in $5 \mathrm{Zj}, \mathrm{m}$.

\begin{tabular}{ccccr}
\hline Year & $\mathrm{a}$ & $\mathrm{b}$ & $\mathrm{r}^{2}$ & $\mathrm{~L}_{50}$ \\
\hline 1986 & -13.399 & 0.302 & 0.96 & 44.4 \\
1987 & -10.323 & 0.223 & 0.90 & 46.3 \\
1988 & -11.225 & 0.258 & 0.95 & 43.4 \\
1989 & -18.990 & 0.427 & 0.99 & 44.4 \\
1990 & -11.830 & 0.271 & 0.98 & 43.7 \\
1991 & -10.060 & 0.235 & 0.93 & 42.8 \\
1992 & -14.639 & 0.358 & 0.97 & 40.8 \\
1993 & -14.812 & 0.358 & 0.94 & 41.4 \\
1994 & -17.233 & 0.417 & 0.93 & 41.3 \\
Mean & -12.098 & 0.281 & 0.96 & 43.1 \\
\hline
\end{tabular}

sion model. The resultant equation was:

weight $(\mathrm{kg})=0.000009122 \times(\text { length in } \mathrm{cm})^{3.03039}$, with $r^{2}=0.997$,

and was used to determine the index of female SSB in tons for each survey year. The three indices are shown in the following text table.

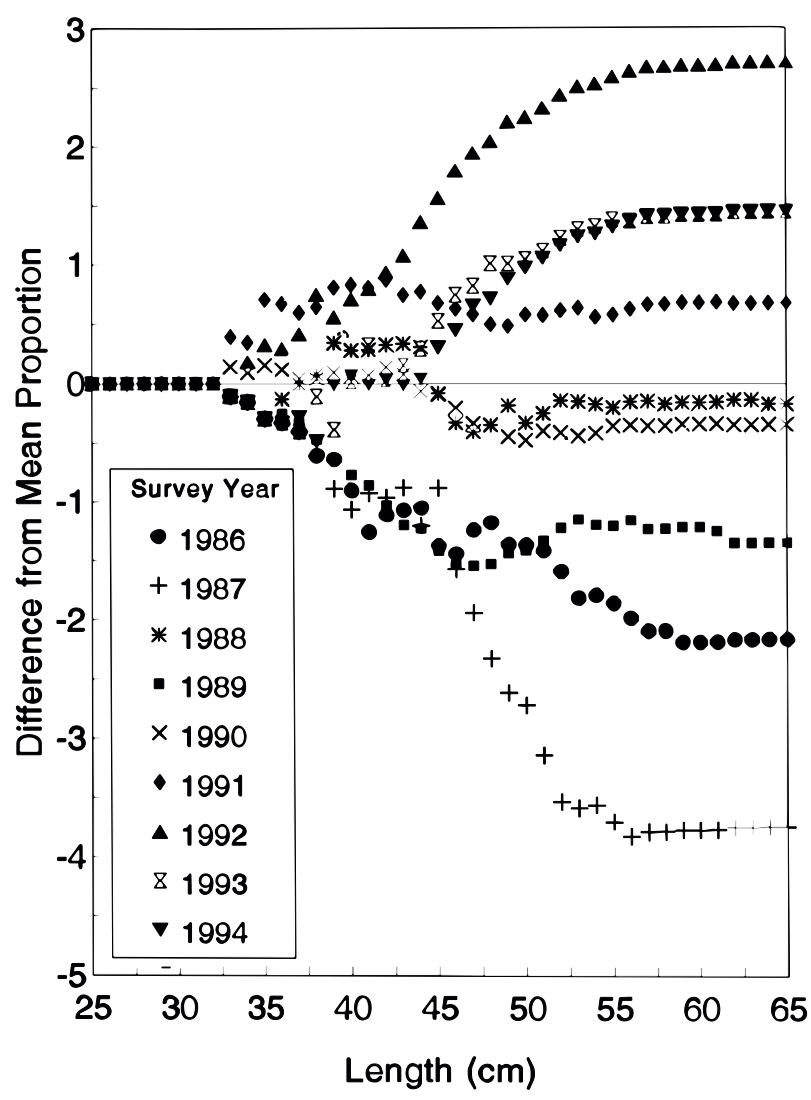

Fig. 6. Cumulative difference from the 1986-94 mean proportion mature-at-length for 1986-94 spring surveys.

\begin{tabular}{lrrrrrr}
\hline Year/Year-class & 1986 & 1987 & 1988 & 1989 & 1990 \\
\hline SSB & 9552 & 13628 & 13031 & 30667 & 19113 \\
$3+^{1}$ & 28967 & 26281 & 39705 & 34322 & 43601 \\
Rect $^{2}$ & 7129 & 13999 & 4056 & 5311 & 10968
\end{tabular}

\begin{tabular}{lrrrr}
\hline Year/Year-class & 1991 & 1992 & 1993 & 1994 \\
\hline SSB & 14098 & 10372 & 16050 & 6491 \\
$3+^{1}$ & 33169 & 22552 & 21043 & 14481 \\
Rect $^{2}$ & 2705 & 1487 & 315 & -
\end{tabular}

$13+$ biomass ( $t$ ) from Hunt and Buzeta (MS 1994).

2 Recruits at age one from Hunt and Buzeta (MS 1994).

There did not appear to be a strong correlation between recruits at age one, and either the $3+$ biomass or the index of female SSB. However, the decline was evident in $3+$ biomass and the index since 1990 tracked the decline in recruitment. Further analysis of a stock recruitment relation was considered to be useful.

Comparison of commercial landings-at-length with the February/March survey indicated a very similar distribution with about $10 \mathrm{~cm}$ offset, which 


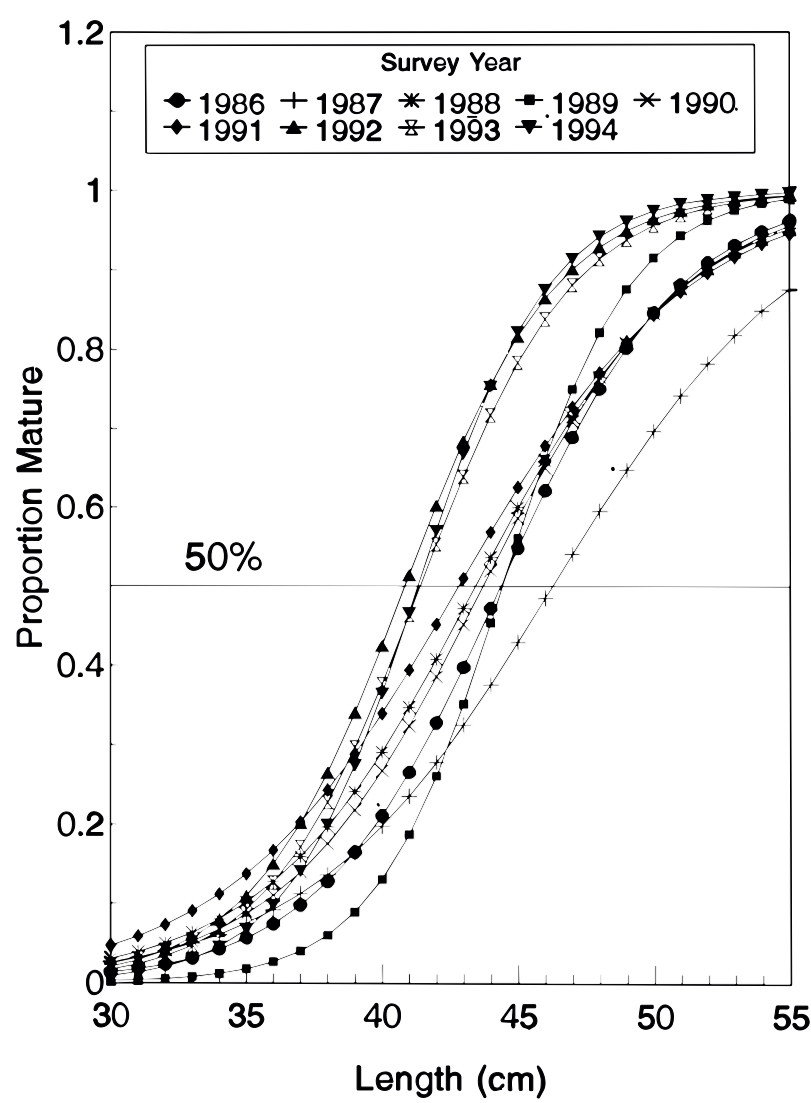

Fig. 7. Annual ogives for maturity-at-length by survey year.

TABLE 7. Parameter estimates for maturity ogives by age and year for cod in $5 \mathrm{Zj}, \mathrm{m}$.

\begin{tabular}{ccccc}
\hline \hline Year & $\mathrm{a}$ & $\mathrm{b}$ & $\mathrm{r}^{2}$ & $\mathrm{Age}_{50}$ \\
\hline 1986 & -5.273 & 2.293 & 0.91 & 2.30 \\
1987 & -4.949 & 2.091 & 0.90 & 2.37 \\
1988 & -7.252 & 3.296 & 0.94 & 2.20 \\
1989 & -8.179 & 3.888 & 0.92 & 2.10 \\
1990 & -8.357 & 3.704 & 0.89 & 2.26 \\
1991 & -8.169 & 4.167 & 0.83 & 1.96 \\
1992 & -10.729 & 5.798 & 0.91 & 1.85 \\
1993 & -11.322 & 6.060 & 0.89 & 1.87 \\
1994 & -6.100 & 2.813 & 0.90 & 2.17 \\
Mean & -5.292 & 2.545 & 0.92 & 2.08 \\
\hline
\end{tabular}

was assumed to represent growth in the March-July time period. Assuming that the majority of growth occurs in the second and third quarter, when the bulk of the commercial fishery takes place, then these results are consistent with length-at-age given in Hunt and Buzeta (MS 1994). They report annual increases of about $10 \mathrm{~cm}$ between age one and two and age two and three, and essentially a linear growth rate between 40 and $70 \mathrm{~cm}$.

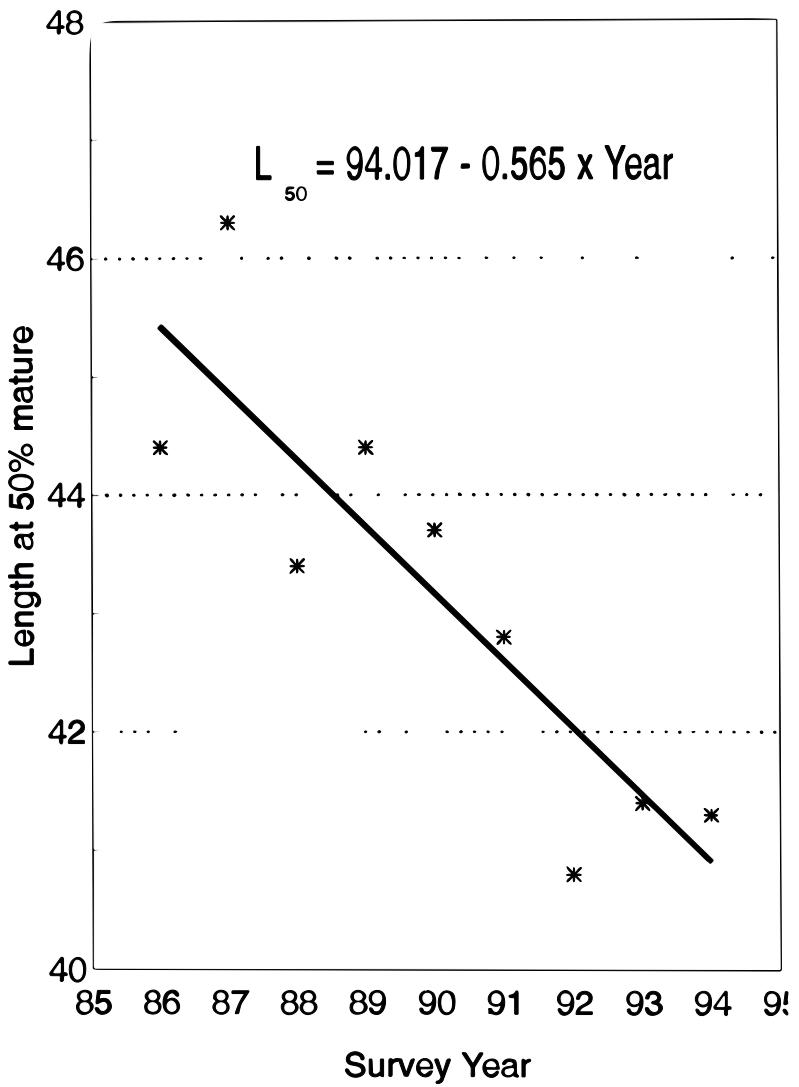

Fig. 8. Regression of length at $50 \%$ maturity on survey year.

Growth model parameters using age in days from survey and commercial samples were estimated as:

$$
\begin{array}{rlr}
\mathrm{L}_{\text {inf }} & =154.93 \mathrm{~cm} & 7.45 \\
\mathrm{k} & =0.000293 & 0.000036 \\
\mathrm{t}_{0} & =-332.24 & 118.07
\end{array}
$$

Using these parameters, age at a length of 31 $\mathrm{cm}$ for example, in the survey was estimated to be 429.72 days. The elapsed time between the mean survey date and fishery date, in 1986, was $=146.5$ days (i.e. 214-67.5, from Tables 1 and 9). The commercial fishery length equivalent of $31 \mathrm{~cm}$ surveycaught fish was the length predicted $36.21 \mathrm{~cm}$ at an age of 576.22 days (i.e. $429.72+146.5$ from Tables 1 and 9). In this example, the net growth between the survey and the fishery was $5.21 \mathrm{~cm}$ and ranged from about $7 \mathrm{~cm}$ and $<1 \mathrm{~cm}$ for the minimum and maximum lengths, respectively.

The proportion of immature fish in commercial landings ranged from about 5\% in 1993 to about $43 \%$ in 1987 by number, and generally less than 


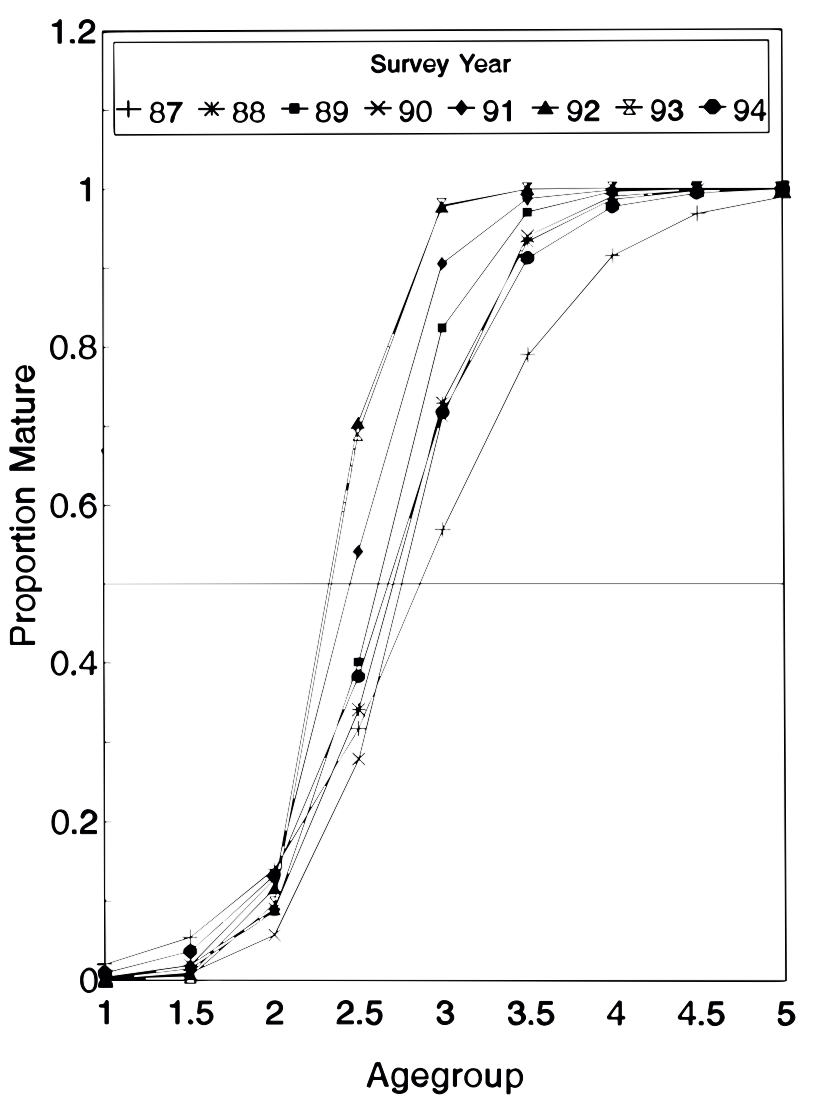

Fig. 9. Annual ogives for maturity-at-age by survey year.

$5 \%$ by weight with the exception of 1987 when about $22 \%$ of the landed weight was immature fish of the 1985 year-class. Results for 1986-93 are summarized in Table 9 and the two extremes for percent of immature fish (1987 and 1993) are shown in Fig. 14.

Application of maturity-at-age to the landingsat-age resulted in similar estimates for the percent of immature fish when compared to those derived from length. Results are given in Table 9, and ranged from $45 \%$ in 1987 to about $3 \%$ in 1993, and there appeared to be no trend in the difference between the length-based and age-based estimates.

At-sea sampling of the Georges Bank cod fishery for 1992 resulted in 268 samples and over 18 000 fish measured for length frequency from mobile and fixed gear catches. Only ten samples of discards were collected consisting of 105 length measurements. No discard samples were taken from fixed gear catches. The low observed numbers of discards indicated that samples of landings were representative of catches.

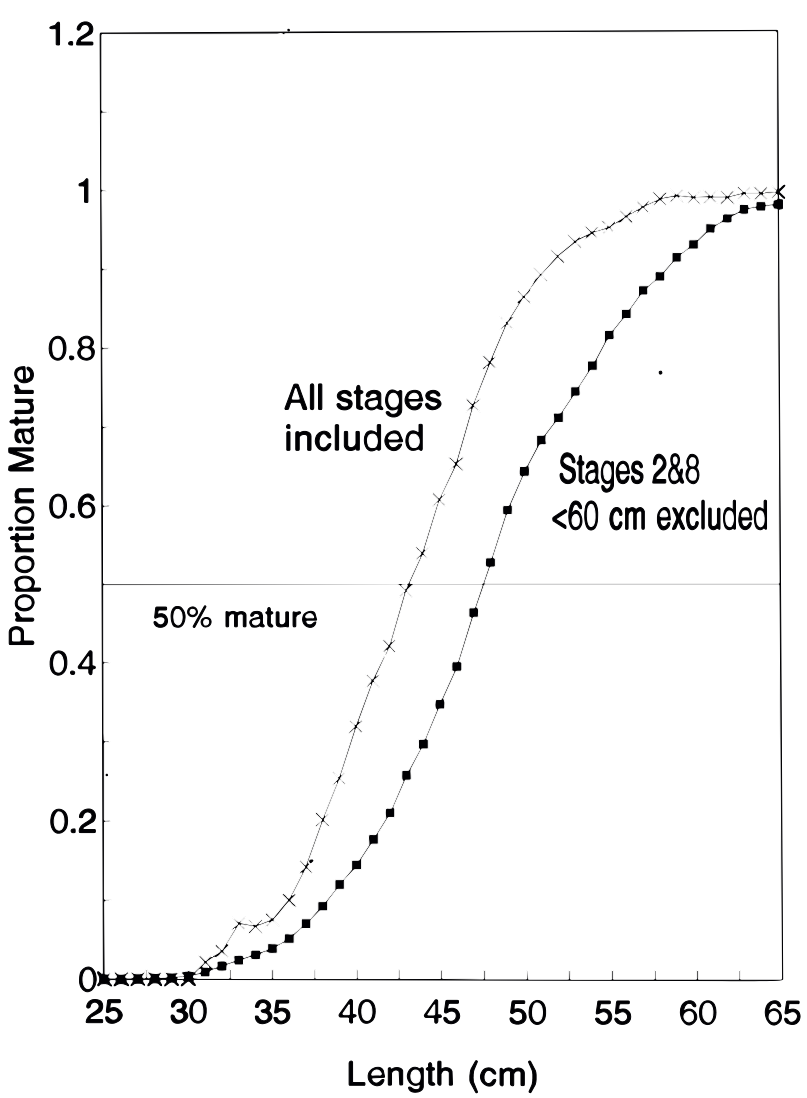

Fig. 10. Mean proportion mature-at-length estimated with and without maturity stages 2 and 6 for fish less than $60 \mathrm{~cm}$.

\section{Discussion}

In the past it has been assumed that mean length-at-age was similar for male and female cod, and therefore sampling designs do not incorporate a sex-specific factor. Observations from this study suggest that there is a significant difference in length at age $4+$ between sexes, and annual estimates had significantly higher mean lengths-at-age for females compared to males. These results are consistent with those reported by O'Brien (MS 1990) and she also concluded that some year-class differences exist for the Georges Bank cod stock.

The use of the logistic model on the data to describe proportion mature in this study appeared to be appropriate. Trippel and Harvey (1991) describe a number of potential models for estimating the proportion of a population mature and conclude that, for a population with Type I (their classification) onset of maturity, a probit or logistic curve was the most appropriate. In this study the cod appeared 


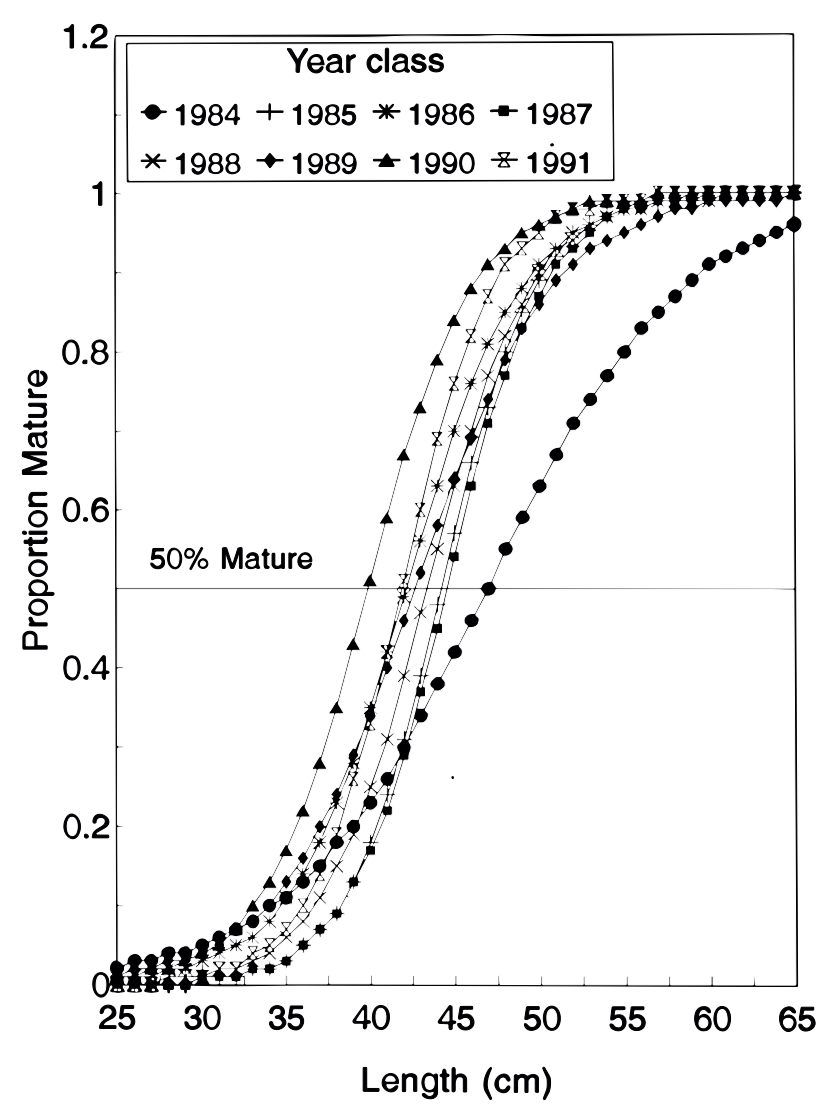

Fig. 11. Proportion mature-at-length for the 1984-91 yearclasses at ages 1-4 from 1986-94.

TABLE 8. Parameter estimates of maturity ogives by yearclass for cod in $5 \mathrm{Zj}, \mathrm{m}$.

\begin{tabular}{ccccc}
\hline \hline Year-class & $\mathrm{a}$ & $\mathrm{b}$ & $\mathrm{r}^{2}$ & $\mathrm{~L}_{50}$ \\
\hline 1984 & -8.145 & 0.174 & 0.74 & 46.8 \\
1985 & -16.206 & 0.367 & 0.97 & 44.2 \\
1986 & -12.369 & 0.294 & 0.96 & 42.1 \\
1987 & -15.657 & 0.352 & 0.98 & 44.5 \\
1988 & -14.290 & 0.330 & 0.98 & 43.3 \\
1989 & -10.584 & 0.248 & 0.92 & 44.1 \\
1990 & -12.856 & 0.323 & 0.98 & 39.8 \\
1991 & -15.575 & 0.372 & 0.92 & 41.9 \\
\hline
\end{tabular}

to conform to Type I in which onset of maturity occurs over either a narrow length or age range. Chen and Paloheima (1994) also report on the appropriateness of a logistic curve for describing maturation rates.

Considerable annual variability existed in the estimates of proportion mature-at-length for males and females. However, there did not appear to be a significant difference between males and females, and the 1987-93 mean maturity ogives for the sexes

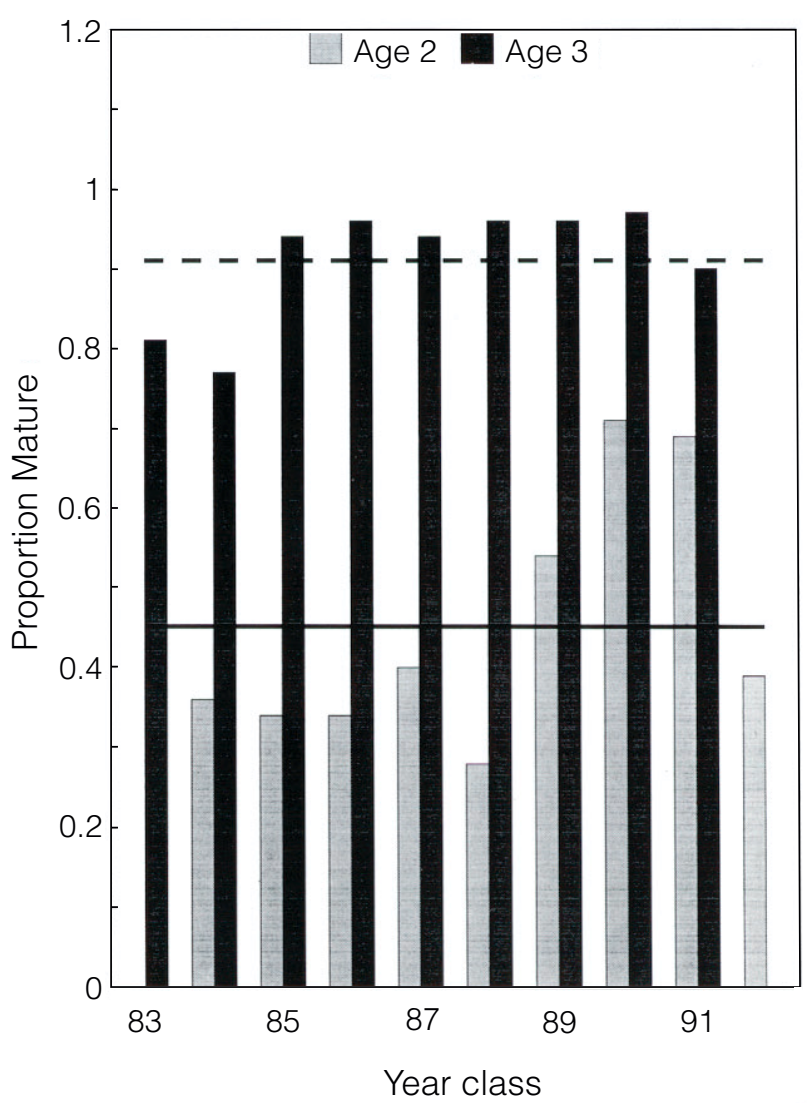

Fig. 12. Estimated proportion mature in the population for the 1983-92 year-classes at ages 2 and 3 .

appeared to coincide. The annual proportion of females of the mature part of the stock was less than $50 \%$ on average overall, but was closer to $65 \%$ for that part of the population at lengths in excess of $100 \mathrm{~cm}$.

Correct assignment to maturity stage or classification as immature or mature is of obvious critical importance to investigation of maturation rates. The high number of stages at the extremes of the maturation cycle (stages 2 and 8 ) during a time when peak spawning activity was thought to occur may be an indication of either incorrect assignment or a protracted spawning season. Exclusion of these stages from the analysis resulted in a substantial shift in the values for $L_{50}$ and for $A_{50}$ but had no apparent impact on the observed trend over time. Results of a study by Annand (C. Annand, Marine Fish Division, Department of Fisheries and Oceans, Dartmouth, Nova Scotia, pers. comm), have indicated a bias in assignment of maturity stage between immature and mature fish with macroscopic examination resulting in a higher proportion of mature fish compared to histological classification. For example, her results for the 1992 survey estimated 


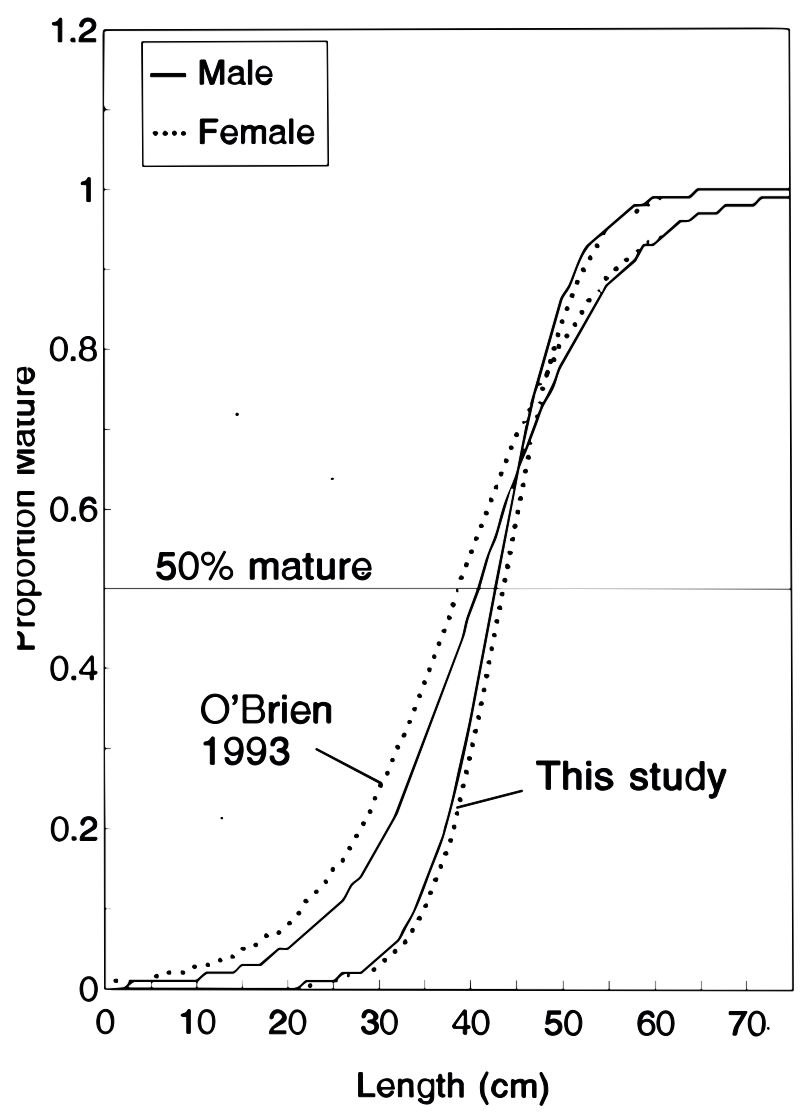

Fig. 13. Comparison of maturity ogives derived in this study with those of O'Brien (1993).
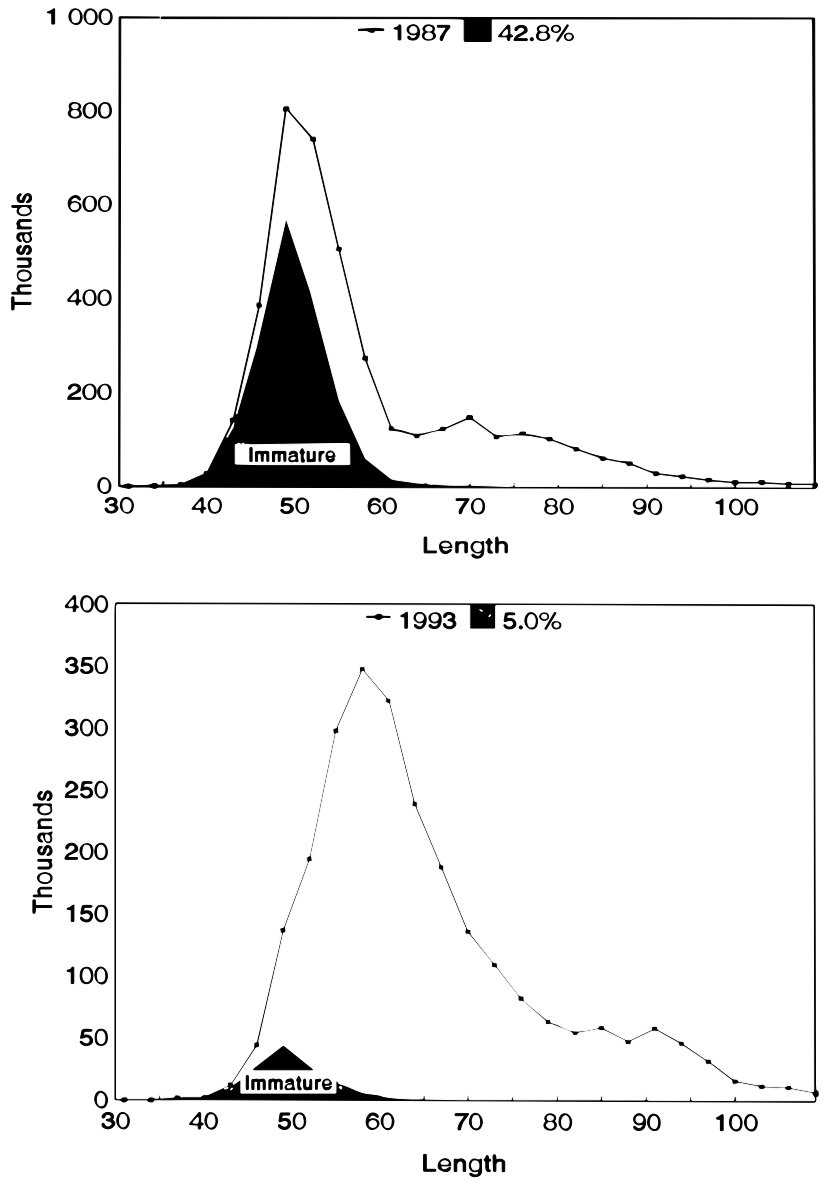

Fig. 14. Canadian commercial landings by length for mature and immature cod on Georges Bank for 1987 and 1993.

TABLE 9. Proportion of immature cod in 5Zj, $m$ for 1986-93 landings.

\begin{tabular}{lrrrrrrrr}
\hline \hline Year & 1986 & 1987 & 1988 & 1989 & 1990 & 1991 & 1992 & 1993 \\
Calendar Day (from 1 Jan) & 214 & 218 & 198 & 200 & 215 & 205 & 196 & 179 \\
\hline $\begin{array}{l}\text { Percent Immature } \\
\quad \text { a) Length-based }\end{array}$ & & & & & & & & \\
$\quad \begin{array}{l}\text { Numbers } \\
\quad \text { Biomass }\end{array}$ & 8.8 & 42.8 & 11.3 & 12.7 & 6.5 & 8.7 & 10.5 & 5.0 \\
b) Age-based & 3.1 & 21.8 & 4.2 & 3.2 & 2.7 & 3.5 & 3.5 & 1.8 \\
$\quad$ & & & & & & & & \\
$\quad$ Numbers & 16.3 & 44.5 & 8.1 & 12.2 & 10.9 & 5.8 & 14.3 & 3.4 \\
\hline
\end{tabular}

$32 \%$ mature for fish $35-55 \mathrm{~cm}(\mathrm{n}=87)$ based on histological classification compared to $82 \%$ based on macroscopic classification. This would imply that the $L_{50}$ values derived in this study from macroscopic maturity assignment may be an overestimate.

There are a number of potential reasons for the difference in estimates of maturity found in this study and those reported by O'Brien et al. (MS 1993). These include the description and assign- ment of maturity stage, geographic distribution of samples and the time of collection. The mean calendar day for the Canadian surveys used in this study was 61 compared to 96 used in the USA surveys. As noted above, the timing of the Canadian survey coincides with peak spawning activity, and maturity stages should indicate spawning activity for the year sampled. The USA survey generally takes place after peak spawning and could therefore represent probable maturity in the next spawning season. However, it seems unlikely that fish as- 
sessed as immature in the Canadian surveys would have progressed to an apparent mature condition thirty days later and well in advance of the next spawning season. The apparent smaller $L_{50}$ for Gulf of Maine cod reported by O'Brien et al. (MS 1993) could also be a factor if a substantial proportion of their samples were collected in the area adjacent to the Gulf of Maine where mixing of the two stocks could influence results. The possible misassignment of mature fish as immature noted above would produce even more divergent results between the two studies.

The significant temporal trend in both the $L_{50}$ and the $A_{50}$ for maturity data, combined by sexes may be a response to high exploitation rates on the stock. Hunt and Buzeta (MS 1994) report fishing mortalities in excess of twice the $F_{0.1}=0.2$ reference level for the stock over the 1978-94 time period. Based on O'Brien's (MS 1990) work, the temporal trend extends back in time and probably started in the early-1980s. Beacham (1983, 1987) also reported a decline in size and age of $50 \%$ maturity for cod on the Scotian Shelf and concluded that exploitation rates could be one of the factors in the decline, although Halliday (1987) questioned the validity of the analysis.

The two alternatives for estimating the maturity composition of a population, length or age, produce similar results. However, there are assumptions and potential biases associated with each. To adjust for growth in length between the time of observing maturity (the survey) and the time at which the derived ogive is applied to the population (the fishery) requires incorporation of a growth model. Use of the age-based ogive assumes that the mix of immature and mature fish-at-age remains constant between the time of the survey and commercial fishery. It also requires application of age keys to both the survey and commercial fishery length data and therefore introduces additional ageing-related error in the estimates. These concerns about maturity-at-age were noted by the Workshop on Sampling Strategies for Age and Maturity (Anon., MS 1994b) as was the generally accepted stronger influence of length rather than age on attaining sexual maturity. The almost knife-edge selection for maturityat-age seen in this cod stock also implies the need for very precise estimation of the ogive and gives further support to use of length based analyses.

Substantial differences exist in the proportion at length landed between fixed and mobile fishing gears in the Georges Bank cod fishery. In 1992, close to $80 \%$ of all otter trawl landings were of cod less than $60 \mathrm{~cm}$ in length and essentially all fish caught and landed exceeded a minimum landed size of $43 \mathrm{~cm}$. This would imply that a conservation goal of avoiding capture and fishing mortality on undersize fish is being achieved in the Georges Bank commercial fishery. Present management regulations aimed at reducing or eliminating the capture and landing of fish less than a defined minimum size through mesh size control, seem to be effective and the use of large mesh size $(145 \mathrm{~mm}$ ) as well as "square" mesh have been generally accepted by industry as an effective way of avoiding catches of small fish. However, a relatively high proportion of "legal" size fish are immature and their capture results in reduced spawning potential for recruiting year-classes. The possible under estimate of $L_{50}$ noted above would also under estimate the catches of immature fish. If a conservation goal was to allow each recruit to spawn at least once prior to being subject to exploitation, then this goal appears not to be met in the Georges Bank cod fishery under existing harvest strategies.

The decline in percent of immature fish in landings for recent years may be a result of more widespread use of larger and square mesh and an increase in the minimum size retained by the net. However, it was apparent from Table 7 that exploitation of recruiting year-classes can be substantial. The 1985, 1987 and 1990 year-classes were above the recent average (Hunt and Buzeta, MS 1994) but high numbers of immature fish from these yearclasses were caught. To further reduce the capture of immature fish would require a substantial increase in mesh size for mobile gear if fish less than about $50 \mathrm{~cm}$ are to be avoided.

Alternative measures to reduce capture of immature fish, such as closure of nursery areas, require detailed knowledge of distribution by maturity. The present distribution of fishing effort in the Georges Bank fishery indicates several areas of dense aggregation along the northeast and northern edges of the Bank. It is probably unlikely, given the expected resolution of distribution at size data, that closure of areas could be sufficiently selective to allow harvest of only mature fish.

An additional consideration in development of conservation measures through harvesting strategies is the mixed species nature of the Georges Bank fishery. Typically, both cod and haddock are taken by the same vessels. Anecdotal information suggests the two species may be separated at some times of the year by preferred depth but generally mixing is extensive. The impact of changes in harvesting strategy for one species would require assessment of the impact (positive, negative or nil) on the other species.

Rebuilding for this stock will be highly dependent on recruitment and the contribution of first time 
spawners, because of the present low stock biomass and small age range (Hunt and Buzeta, 1994). Trippel et al. (1995) note that reproductive success of cod is related to both the size and age of first maturity and the age structure of the mature component of the population which may be a further concern for the Georges Bank cod population.

\section{Acknowledgements}

The author extends thanks to Dr Ed Trippel and Ms Chris Annand for their careful review of an earlier version of the manuscript. Their comments improved the presentation and interpretation of the analyses. Also the comments by two anonymous reviews are appreciated. The staff and crew of the Alfred Needler are thanked for their dedication and fortitude in collecting the data during winter research surveys of the Georges Bank area.

\section{References}

ANON. MS 1994a. Report of the 18th Northeast Regional Stock Assessment Workshop. NMFS/NEFC, Woods Hole, Lab. Ref. Doc., No. 94-01, 71 p.

MS 1994b. Report of the Workshop on Sampling Strategies for Age and Maturity. ICES C.M. DOC., No. D:1: 19-67.

BEACHAM, T. D. 1983. Variability in median size and age at sexual maturity of Atlantic cod on the Scotian Shelf in the Northwest Atlantic Ocean. Fish. Bull. U.S., 81: 303-321.

1987. Variability in median size and age at sexual maturity of Atlantic groundfish: a reply. Envir. Biol. of Fishes, Vol. 19(2): 149-153.

BUZETA, M-I, J. HUNT, L. VanEECKHAUTE, and N. MUNROE. MS 1992. Georges Bank cod ageing workshop. CAFSAC Res. Doc., No. 119: 34.

BURNETT, J, L. O'BRIEN, R. MAYO, J. DARDE, and M. BOHAN. MS 1989. Finfish maturity sampling and classification schemes used during Northeast Fisheries Center bottom trawl surveys, 1963-89. NOAA Tech. Mem. NMFS-F/NEC-76, $14 \mathrm{p}$. .
CHEN, Y., and J. E. PALOHEIMO. 1994. Estimating fish length and age at $50 \%$ maturity using a logistic type model. Aquatic Sciences, 56/3: 206-219.

HALLIDAY, R. G. 1987. Variability in median size and age at sexual maturity of Atlantic groundfish: a critique. Envir. Biol. of Fishes, Vol. 19(2): 139-147.

HUNT, J. J., and M-I. BUZETA. 1992. Status of the Atlantic cod stock on Georges Bank in unit areas $5 \mathrm{Zj}$ and 5Zm, 1978-91. DFO Atl. Fish. Res. Doc., No. 48, $23 \mathrm{p}$.

HUNT, J. J. 1989. Status of the Atlantic Cod Stock on Georges Bank in Unit Areas 5Zj and 5Zm, 1978-88. CAFSAC Res. Doc., No. 47, 26 p.

NI, I-H., and E. J. SANDEMAN. 1984. Size at maturity for northwest Atlantic redfishes. Can. J. Fish. Aquat. Sci., 41: 1753-1762.

O'BRIEN, L. MS 1990. Effects of fluctuations in stock abundance upon the life history parameters of Atlantic cod for the 1970-87 year-classes from the Georges Bank and Gulf of Maine. M. Sci. Thesis. Univ of Washington, Seattle, WA., $95 \mathrm{p}$.

O'BRIEN, L., J. BURNETT, and R. MAYO. MS 1993. Maturation of nineteen species of finfish off the Northeast coast of the United States, 1985-90. NOAA Tech. Rep. NMFS 113: $66 \mathrm{p}$.

SINCLAIR, A. (ed.) 1993. Report on the assessments of groundfish stocks in the Canadian Northwest Atlantic May 4-14, 1993. Can. Tech. Rep. Fish. Aquat. Sci., 1946e, $200 \mathrm{p}$.

SMITH, S. J., and G. D. SOMERTON. 1981. STRAP: A user-oriented computer analysis system for groundfish research trawl survey data. Can. Tech. Rep. Fish. Aquat. Sci., 1030: iv + 66 p.

TRIPPEL, E. A., and H. H. HARVEY. 1991. Comparison of methods used to estimate age and length of fishes at sexual maturity using populations of white sucker (Catostomus commersoni). Can J. Fish. Aquat. Sci., 48: 1446-1459.

TRIPPEL, E. A., M-I. BUZETA, and J. J. HUNT. 1995. Evaluation of the cost of reproduction in Georges Bank Atlantic cod: Utility of otolith back-calculation. In: Recent Developments in Fish Otolith Research.Fish. Secor, D. H., J. M. Dean and S. E. Campana, (eds). U. South Carolina Press, Columbia, South Carolina, USA: 599-616. 
Appendix I. Macroscopic definition of maturity stages for cod used on Canadian research surveys

\begin{tabular}{|c|c|c|c|}
\hline & & Female & Male \\
\hline Stage 1 & $\begin{array}{l}\text { Immature } \\
\text { (Immature) }\end{array}$ & $\begin{array}{l}\text { Ovaries small and firm; pale pink or reddish } \\
\text { and somewhat transparent. }\end{array}$ & $\begin{array}{l}\text { Testes slender; appear as a clear, crimped } \\
\text { and slender string. }\end{array}$ \\
\hline Stage 2 & $\begin{array}{l}\text { Ripening 1 } \\
\text { (Ripening 1) }\end{array}$ & $\begin{array}{l}\text { Ovaries slightly larger than in I but still } \\
\text { small and firm; contains microscopic, yellow, } \\
\text { or reddish yellow, opaque eggs; blood capil- } \\
\text { laries showing. }\end{array}$ & $\begin{array}{l}\text { Testes grow gradually in size; pinkish or } \\
\text { flesh coloured; blood capillaries showing. }\end{array}$ \\
\hline Stage 3 & $\begin{array}{l}\text { Ripening } 2 \\
\text { (Ripening 2) }\end{array}$ & $\begin{array}{l}\text { Ovaries occupy about half of ventral cavity; } \\
\text { reddish and numerous blood vessels; opaque } \\
\text { eggs are now visible to naked eye and give } \\
\text { the ovaries a granular appearance. }\end{array}$ & $\begin{array}{l}\text { Testes occupy about half ventral cavity; be- } \\
\text { gin to turn white, with fine, rather conspicu- } \\
\text { ous blood vessels; no milt runs when pres- } \\
\text { sure is applied. }\end{array}$ \\
\hline Stage 4 & $\begin{array}{l}\text { Ripe } \\
\text { (Ripe) }\end{array}$ & $\begin{array}{l}\text { Has a few clear eggs at the earliest stage } \\
\text { progressing to having mainly clear eggs but } \\
\text { eggs do not extrude freely with slight } \\
\text { pressure. Spawning has not started. }\end{array}$ & $\begin{array}{l}\text { Testes distinctly wavy white and quite dis- } \\
\text { tended; large lobes; a small amount of milt } \\
\text { may be forced by pressure. }\end{array}$ \\
\hline Stage 5 & $\begin{array}{l}\text { Spawning } \\
\text { (Spawning) }\end{array}$ & $\begin{array}{l}\text { As Stage IV but eggs running freely on slight } \\
\text { pressure. }\end{array}$ & $\begin{array}{l}\text { Testes very white and fully extended; milt } \\
\text { runs freely at the slightest pressure. }\end{array}$ \\
\hline Stage 6 & $\begin{array}{l}\text { Spent } \\
\text { (Spent) }\end{array}$ & $\begin{array}{l}\text { Ovaries soft; flabby and bloody; practically no } \\
\text { eggs remain; purple in colour. }\end{array}$ & $\begin{array}{l}\text { Testes shrunken and reddish; vas deferens } \\
\text { prominent against irregular surfaces of tes } \\
\text { tes; some blood left in organ. }\end{array}$ \\
\hline Stage 7 & $\begin{array}{l}\text { Recovering } \\
\text { (Recovering) }\end{array}$ & $\begin{array}{l}\text { Membrane purplish and ovaries fairly baggy, } \\
\text { no eggs visible. }\end{array}$ & $\begin{array}{l}\text { Testes resume pale pink colour; traces of } \\
\text { blood in organ; vas deferens wrinkled and } \\
\text { string-like. }\end{array}$ \\
\hline Stage 8 & $\begin{array}{l}\text { Resting } \\
\text { (Resting) }\end{array}$ & $\begin{array}{l}\text { Looks very much like Stage I, but is found in } \\
\text { large fish; ovary larger than in I, also mem- } \\
\text { brane thicker and not as transparent as in I. }\end{array}$ & $\begin{array}{l}\text { Testes larger than in } 1 \text {; surface regular, } \\
\text { some greyish pink in colour. }\end{array}$ \\
\hline
\end{tabular}



Appendix I. Macroscopic definition of maturity stages for cod used on Canadian research surveys

\begin{tabular}{|c|c|c|c|}
\hline & & Female & Male \\
\hline Stage 1 & $\begin{array}{l}\text { Immature } \\
\text { (Immature) }\end{array}$ & $\begin{array}{l}\text { Ovaries small and firm; pale pink or reddish } \\
\text { and somewhat transparent. }\end{array}$ & $\begin{array}{l}\text { Testes slender; appear as a clear, crimped } \\
\text { and slender string. }\end{array}$ \\
\hline Stage 2 & $\begin{array}{l}\text { Ripening } 1 \\
\text { (Ripening 1) }\end{array}$ & $\begin{array}{l}\text { Ovaries slightly larger than in I but still } \\
\text { small and firm; contains microscopic, yellow, } \\
\text { or reddish yellow, opaque eggs; blood capil- } \\
\text { laries showing. }\end{array}$ & $\begin{array}{l}\text { Testes grow gradually in size; pinkish or } \\
\text { flesh coloured; blood capillaries showing. }\end{array}$ \\
\hline Stage 3 & $\begin{array}{l}\text { Ripening } 2 \\
\text { (Ripening 2) }\end{array}$ & $\begin{array}{l}\text { Ovaries occupy about half of ventral cavity; } \\
\text { reddish and numerous blood vessels; opaque } \\
\text { eggs are now visible to naked eye and give } \\
\text { the ovaries a granular appearance. }\end{array}$ & $\begin{array}{l}\text { Testes occupy about half ventral cavity; be- } \\
\text { gin to turn white, with fine, rather conspicu- } \\
\text { ous blood vessels; no milt runs when pres- } \\
\text { sure is applied. }\end{array}$ \\
\hline Stage 4 & $\begin{array}{l}\text { Ripe } \\
\text { (Ripe) }\end{array}$ & $\begin{array}{l}\text { Has a few clear eggs at the earliest stage } \\
\text { progressing to having mainly clear eggs but } \\
\text { eggs do not extrude freely with slight } \\
\text { pressure. Spawning has not started. }\end{array}$ & $\begin{array}{l}\text { Testes distinctly wavy white and quite dis- } \\
\text { tended; large lobes; a small amount of milt } \\
\text { may be forced by pressure. }\end{array}$ \\
\hline Stage 5 & $\begin{array}{l}\text { Spawning } \\
\text { (Spawning) }\end{array}$ & $\begin{array}{l}\text { As Stage IV but eggs running freely on slight } \\
\text { pressure. }\end{array}$ & $\begin{array}{l}\text { Testes very white and fully extended; milt } \\
\text { runs freely at the slightest pressure. }\end{array}$ \\
\hline Stage 6 & $\begin{array}{l}\text { Spent } \\
\text { (Spent) }\end{array}$ & $\begin{array}{l}\text { Ovaries soft; flabby and bloody; practically no } \\
\text { eggs remain; purple in colour. }\end{array}$ & $\begin{array}{l}\text { Testes shrunken and reddish; vas deferens } \\
\text { prominent against irregular surfaces of tes } \\
\text { tes; some blood left in organ. }\end{array}$ \\
\hline Stage 7 & $\begin{array}{l}\text { Recovering } \\
\text { (Recovering) }\end{array}$ & $\begin{array}{l}\text { Membrane purplish and ovaries fairly baggy, } \\
\text { no eggs visible. }\end{array}$ & $\begin{array}{l}\text { Testes resume pale pink colour; traces of } \\
\text { blood in organ; vas deferens wrinkled and } \\
\text { string-like. }\end{array}$ \\
\hline Stage 8 & $\begin{array}{l}\text { Resting } \\
\text { (Resting) }\end{array}$ & $\begin{array}{l}\text { Looks very much like Stage I, but is found in } \\
\text { large fish; ovary larger than in I, also mem- } \\
\text { brane thicker and not as transparent as in I. }\end{array}$ & $\begin{array}{l}\text { Testes larger than in } 1 \text {; surface regular, } \\
\text { some greyish pink in colour. }\end{array}$ \\
\hline
\end{tabular}

